\title{
Petro-Mineralogical Analysis of Sedimentary Phosphate of Marine Origin, Case of the Locality of El Kouif (Algerian-Tunisian Confines)
}

\author{
Salim Boulemia', Messaoud Hamimed', Salah Bouhlel'2, Jaloul Bejaoui² \\ ${ }^{1}$ Department of Earth Sciences and the Universe, University of Tebessa, Tebessa, Algeria \\ ${ }^{2}$ Department of Earth Sciences, Faculty of Science, University of Tunis, Tunis, Tunisia \\ Email: boulemia_salim@yahoo.fr
}

Received 25 February 2015; accepted 20 March 2015; published 25 March 2015

Copyright (C) 2015 by authors and Scientific Research Publishing Inc.

This work is licensed under the Creative Commons Attribution International License (CC BY).

http://creativecommons.org/licenses/by/4.0/

\section{(c) (i) Open Access}

\section{Abstract}

The sedimentary phosphate of marine origin mark the Paleo-Eocene period in the region of Tebessa, as elsewhere in northern Africa. The study sector of El Kouif is considered as a part of the eastern Saharan Atlas. The lithological description of the studied Cups has allowed showing a bundle of phosphate take by carbonate formations sprinkle of flint. The grain size analysis of sandy phosphorites revealed phospharenite deposits which were generally heterometric and misclassified. Moreover, the mineralogical and magnetic analysis of some samples of phosphatic sands showed a predominance of light minerals. As well as the sorting and morphoscopic observation led the isolation of coprolites, of fossil teeth of fish and lithoclasts but mainly ovoid phosphatic pellets. The XRD analysis confirmed the presence of apatitic minerals (Hydroxyapatite, Fluroapatite, francolite and Dahlias), of carbonates (Calcite, Magnesium calcite, Ankerite, dolomite), the quartz, opal-CT and even sulphides and gypsum. The petrographic analysis of phosphate samples has permit to surround primordially, a phosphatic pellets rich in organic matter, devoid of nucleus and others nucleated. The phases of connections are clay, carbonate or silica. The notable amounts of allochems have an impact on textures of type wackstone, packstone, and sometimes grainstone for bio-pel-microspars.

\section{Keywords}

Sedimentary Phosphate, Paleo-Eocene, Tebessa, Apatite, Allochems 


\section{Introduction}

Phosphate deposits are widely distributed in the stratigraphic scale and one knows the deposits or concentrations virtually in all systems. The paleo-eocene period, mainly the Thanethien [1] in the region of Tebessa, as elsewhere in Northern Africa, is considered privileged or polytaxic type to the phosphatogenesis of marine sedimentary origin.

Tunisian sedimentary phosphates have been the subject of several studies ([2]-[9], however few Algerian scientists who developed geological research on sedimentary phosphates [10] [11]. As a matter of fact, these studies have shown that this phosphate rock often belongs to the class of phosphorescent and sometimes to the phosphate. The allochems elements are generally in order of abundance; pellets, coprolites, the lithoclast, phosphate microorganisms, bone debris and fish teeth. In addition, the binding phase can be; clay, carbonate, silica and rarely apatite. Thus, mineralogical contributions of these sedimentary origin phosphates revealed, francolite, fluorapatite and hydroxylapatite varieties, whose parameters “a” ranges from 9304 to $9331 \AA$.

This work has been proposed in order to know and to better elucidate the petro-mineralogical characteristics of sedimentary phosphates of marine origin of El Kouif. So it would clarify the mechanisms and conditions prevailed for palaeocene phosphatogenesis in the area of Algerian-Tunisian border.

\section{Geographical and Geological Context}

The study area "Djebel Kouif” is part of the Saharan Atlas of eastern Algerian-Tunisian border. This synclinal line extends in Tunisia and localizes $2 \mathrm{~km}$ from the village of El Kouif. It is far $25 \mathrm{~km}$ North-east from the capital of Tebessa (Figure 1).

The main geological formations encountered in the El Kouif sector are Cenozoic in [12] [13] (Figure 2).

a) The Paleocene: this course is divided into three members that are from bottom to top:

- The argillaceous limestone alternating with marls microfauna Globigerina (Danian).

- Marl gray and homogeneous bosom where grows rich coquina (Montian).

- Argillaceous limestone with chert nodules admitting their bottom intercalated phosphate-rich with fish teeth (Thanetian).

b) The Eocene: is a group composed mainly of massive limestone coarse flint nodules and are recognized Nummulites (Ypresian and lower Lutetian).

c) The Neogene: is a continental formation represented mainly by quartz sand and gravel cross stratification.

d) The quaternary: constituted of deposits occupying the plains and mountains feet.

\section{Materials and Methods}

\subsection{Work of Land}

First it was inevitable in the early fieldwork to do some geological routes of recognitions. You should choose

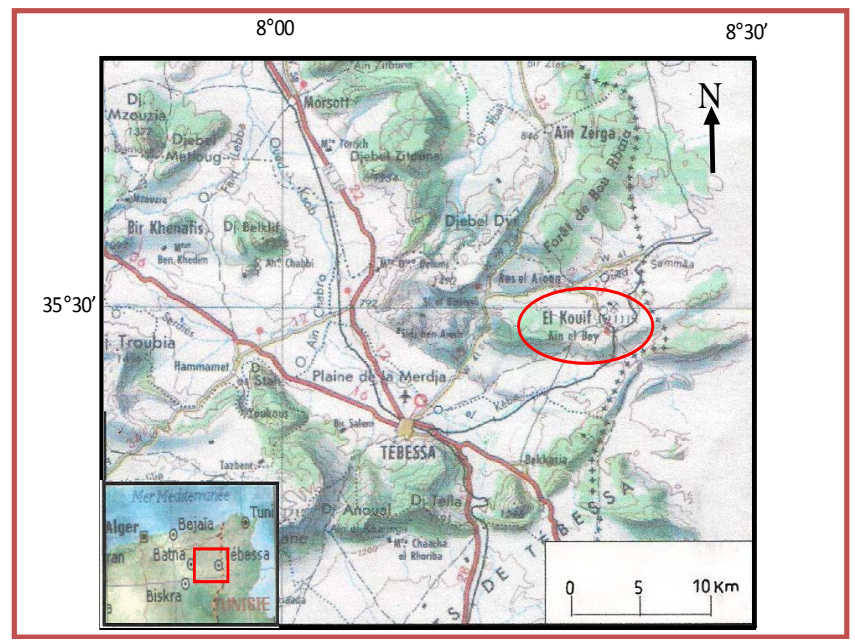

Figure 1. Geographic situation map of the study sector of El Kouif. 


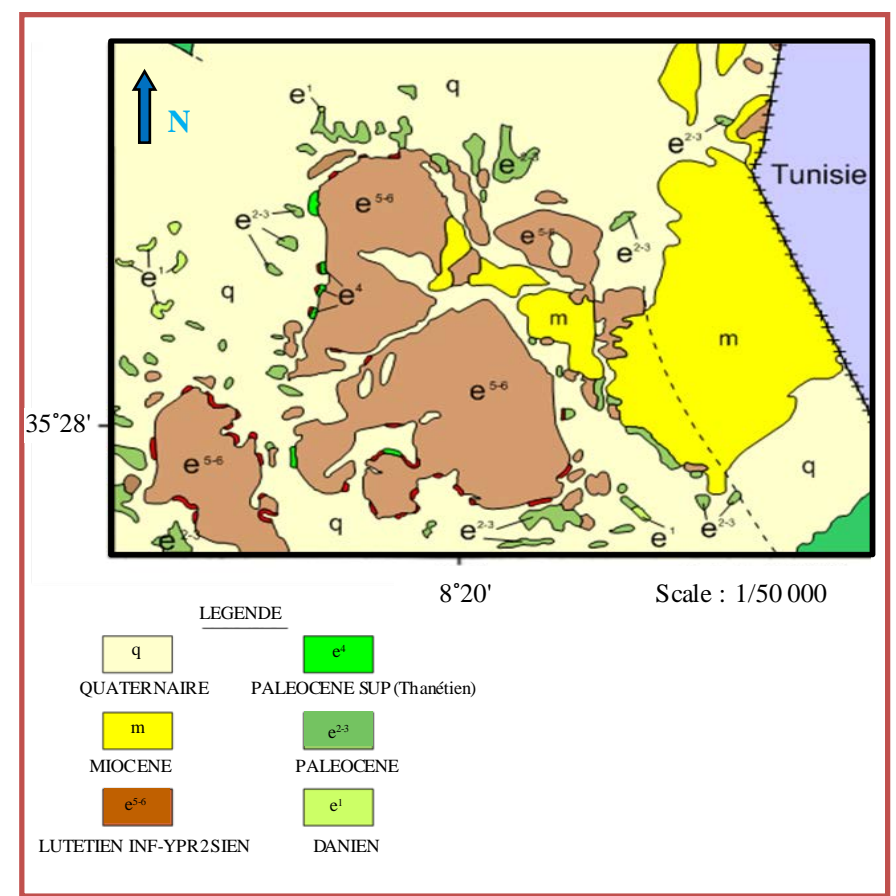

Figure 2. Geologic map of the region of El Kouif (Extracted from the paper number 151.

carefully the location of the sampling beam and phosphate rock. In addition, sampling was instantly accompanied by a sketch on the ground. In total, 53 samples were collected in the three sections of El kouif site (Photo 1) to adequately satisfy the various petro-mineralogical analyzes in the laboratory of geology at the University of Tebessa and the Faculty of Science of Tunis.

\subsection{Laboratory Work}

\subsubsection{Granulometric Analysis}

\section{1) Screening}

The samples of phosphorites to clay cement are relatively brittle and this allows optimal screening. Actually after simple disaggregation is performed a sieve under running water through sieve columns. The analysis is to take the refusal of each sieve and weighed on an electric balance in grams. The initial weight is approximately $100 \mathrm{~g}$ for each sample.

\section{2) Statistical treatment}

The sample of each partial rejection for the database for all statistical calculations. Otherwise, draw histograms and frequency curves to define the modes, asymmetry frequency curve, angularity curve, curves and cumulative particle size according to K. Wentworth purpose of obtaining different transformable (mm) percentiles unit $(\varphi)$. These are the subject of calculating coefficients sedimentological: The median (Md): The percentiles (C): The aveage diameter $(\mathrm{Mz})$ : The average ranking ( $\delta \mathrm{i})$ (dispersion): Asymmetry "skewness" (SKi) "Graphic kurtosis (KG)".

\subsubsection{Mineralogical Analysis}

\section{1) The Leaguers dense (bromoform )}

The particle size fraction (separation between $2 \mathrm{~mm}$ and $0.2 \mathrm{~mm}$ ) were first washed and then dried. The sediment is paid more in the funnel, previously filled halfway bromoform. The mixture was vigorously stirred and the mixture was allowed to stand. It opens gently tap the funnel to collect the heavy minerals falling on the bottom thereof. However light mineral float on the surface of bromoform. Rinsing minerals ethyl alcohol at $90^{\circ}$ is required.

\section{2) Magnetic separation}




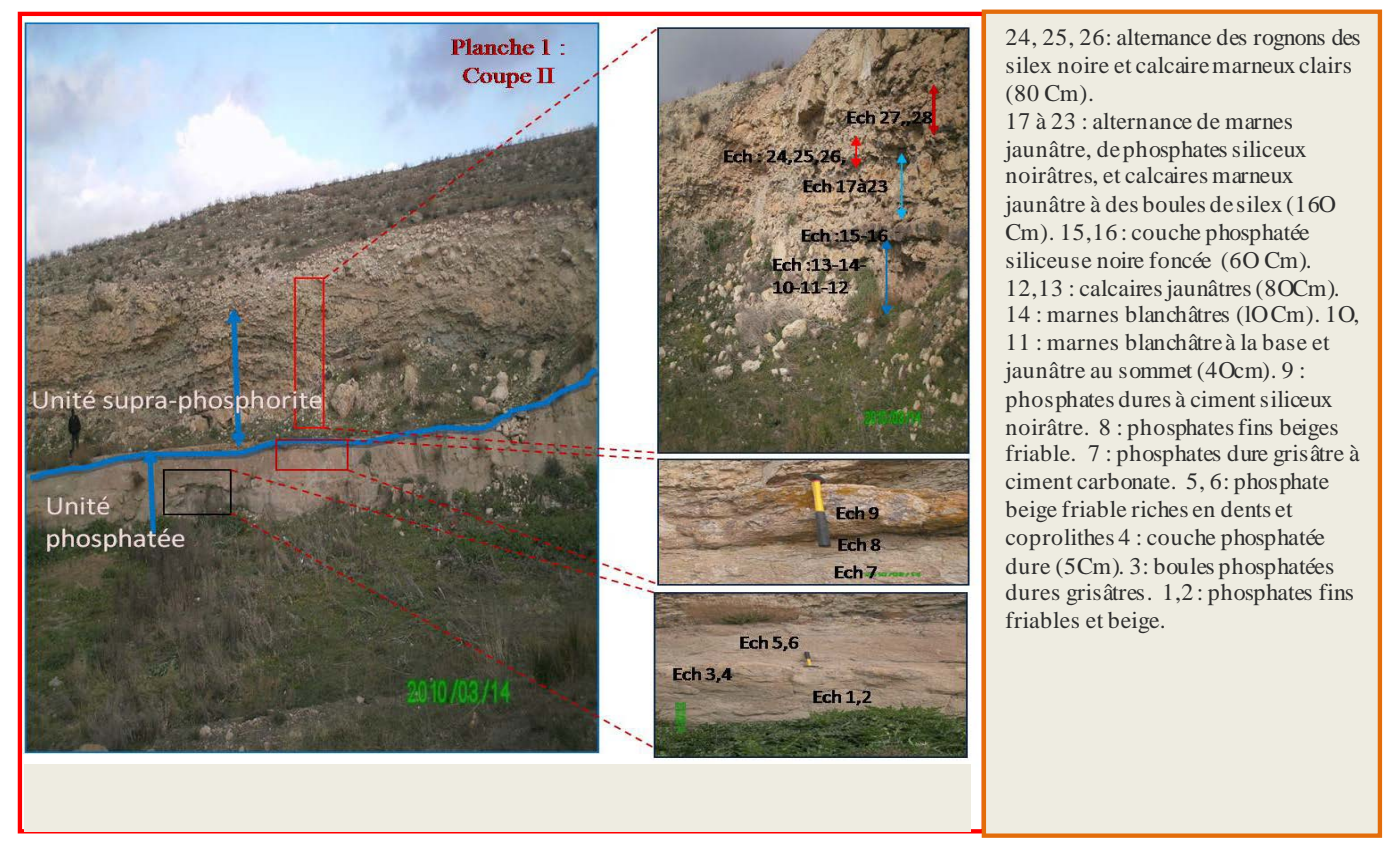

Photo 1. Representation of geologic section No. 2 from El Kouif sector.

The permanent magnet surrounded by a paper cap is passed over the powder is spread in a thin layer on a sheet of paper. The iron fraction is attracted and sticks to the magnet. After, simply drag away the cap to the poles of the magnet and dropping.

\section{3) Sorting and morphoscopic observation}

Categories are part of the coarse fraction or class of rudites, namely coprolites, teeth, bone fragments and lithoclasts are isolated by visual pecking live post-screening, and will undergo an identifying description under binocular.

\section{4) X Ray diffractometry}

The samples even clay, are previously ground to a particle size close to $30 \mathrm{~mm}$. The resulting powder was analyzed by X diffractometer, model X'Pert Pro Panatycal rays, the Common Services Unit for Research in the Faculty of Sciences of Tunis. The type of acquisition parameters is used for routine analysis (no $=0.02^{\circ}$ and time/step = $20 \mathrm{~s}$ ) for the identification and quantification of different crystalline phases present in a sample. The $\mathrm{X}$-ray diffractogram obtained from a multiphase powder is compared by computer with all records database using a "High Scoreplus" program. Database used is the Powder Diffraction File (PDF) with more than 164,000 pages, published in 2004 by the International Center of diffraction Data (ICDD). The determination of the crystallographic parameters of a given phase is performed using the same software.

\subsubsection{Petrographic Analysis}

The preparation of thin sections and polished sections achievement are out of pocket in the laboratory Tebessa. For the study was used Leica polarizing microscopes DMLP specially adapted for all petrographic observations in transmitted and reflected light.

\section{Results and Discussions}

In El kouif sector three sections were selected. They represent the Paleo-Eocene sedimentation where the phosphate beam follows a carbonate-clay cover dotted with flint. The macroscopic findings of land enumerated upward succession overlying levels (the phosphate beam) as follows:

a) Marne whitish and yellowish base a top thickness of about $40 \mathrm{~cm}$.

b) Limestone yellowish thick $80 \mathrm{~cm}$.

c) Intercalation $10 \mathrm{~cm}$ whitish marl.

d) Siliceous layer of phosphate black dark thick $60 \mathrm{~cm}$. 
e) Alternations order decimeter horizons yellowish marl, siliceous phosphates black and yellow limestone pellets flint, the total is about $160 \mathrm{~cm}$.

f) A mix of the kidneys of black flint and limestone yellowish $140 \mathrm{~cm}$ thick.

g) Bench yellowish limestone thickness of about $150 \mathrm{~cm}$.

All phosphate samples that have been size analysis are usually friable beige to light beige/gray or blackish gray. These phosphorites are generally equigranular and sometimes heterometric to clay cement undeveloped appearance.

Treatment and recounts the data size analysis has to decide on relevant outcomes including: Histograms and frequency curves show complex behavior of several modes. These reflect the mixture of multiple size fractions. Furthermore, sedimentological coefficients provide information on:

- Values of Skewnes faithfully reflecting the complex shapes of histograms.

- The frequency curves are usually multiple graphic types indicating the Kurtosis.

- The median values calculated are included primarily in the sand fraction of medium and fine sizes.

- The figures calculated percentiles end to class rudites (granules).

- Values are mean diameters of classes of sands and medium end.

- The dispersion values are classified in the interval (1.2) which is learning about grains misclassified.

The sum in fractions analyzed show a certain predominance of grains of sand fine and very fine with an occasional enrichment of coarse and very coarse (Rudites). In other words, it is mainly the result that they are fine sandy phosphorites very fine ( $40 \%$ - 50\% arenites) with a moderately lower of $5 \%$ to $8 \%$ clay cement.

All phosphate samples that have been size analysis are usually friable beige to light beige/gray or blackish gray. These phosphorites are generally equigranular and sometimes heterometric to clay cement undeveloped appearance.

About Granulometric analysis, the treatment and recounts the data size analysis (Table 1) has to decide on relevant outcomes including: Histograms and frequency curves (Figure 3) show complex behavior of several modes. These reflect the mixture of multiple size fractions. Furthermore, sedimentological coefficients provide information on (Table 2):

Table 1. Granulometric analysis results for sample 2, section II.

\begin{tabular}{|c|c|c|c|c|c|c|c|c|c|}
\hline \multicolumn{2}{|c|}{ Diamètre des tamis } & \multicolumn{2}{|c|}{ Refus partiels } & \multicolumn{3}{|c|}{ Refus cumules Tamis cumulés Percentiles } & \multirow[b]{2}{*}{$\varphi$} & \multicolumn{2}{|c|}{ Dénomination selon Wentworth } \\
\hline$\Phi$ & $\mathrm{mm}$ & g & $\%$ & $\%$ & $\%$ & $\varphi \mathrm{i}$ & & & \\
\hline-2 & 4 & 2.7 & 3.25 & 3.25 & 100.00 & & & (Granule) & Gravier \\
\hline-1.65 & 3.15 & 2.3 & 2.77 & 6.02 & 96.76 & $\varphi 99$ & -1.89 & Très fin & \\
\hline-1 & 2 & 5.2 & 6.26 & 12.28 & 93.99 & $\varphi 95$ & -1.24 & Très grossier & Sable \\
\hline-0.67 & 1.6 & 3.1 & 3.73 & 16.01 & 87.73 & & & & \\
\hline-0.32 & 1.25 & 2.8 & 3.37 & 19.38 & 84.00 & $\varphi 84$ & -0.32 & & \\
\hline 0 & 1 & 5 & 6.02 & 25.39 & 80.63 & & & grossier & \\
\hline 0.32 & 0.8 & 4.2 & 5.05 & 30.45 & 74.61 & $\varphi 75$ & 0.30 & & \\
\hline 0.67 & 0.63 & 2.3 & 2.77 & 33.21 & 69.56 & & & & \\
\hline 1 & 0.5 & 3.3 & 3.97 & 37.19 & 66.79 & & & fin & \\
\hline 1.32 & 0.4 & 4.6 & 5.54 & 42.72 & 62.82 & & & & \\
\hline 1.67 & 0.315 & 6.3 & 7.58 & 50.30 & 57.29 & & & & \\
\hline 2 & 0.25 & 9.3 & 11.19 & 61.49 & 49.70 & $\varphi 50$ & 1.99 & moyen & \\
\hline 2.32 & 0.2 & 8.8 & 10.59 & 72.08 & 38.51 & & & & \\
\hline 2.64 & 0.16 & 7.2 & 8.66 & 80.75 & 27.92 & & & & \\
\hline 3 & 0.125 & 8.6 & 10.35 & 91.10 & 19.26 & $\varphi 25$ & 2.76 & Très fin & \\
\hline 3.32 & 0.1 & 1.4 & 1.68 & 92.78 & 8.91 & $\varphi 16$ & 3.10 & & \\
\hline 3.64 & 0.08 & 0.6 & 0.72 & 93.50 & 7.23 & & & & \\
\hline 4 & 0.063 & 3.6 & 4.33 & 97.83 & 6.50 & & & & Silt \\
\hline 4.6 & 0.04 & 0.3 & 0.36 & 98.20 & 2.17 & $\varphi 5$ & 4.21 & & Argile \\
\hline \multirow[t]{2}{*}{$<4.6$} & $<.04$ & 1.5 & 1.81 & 100.00 & 1.81 & & & & \\
\hline & Total: & 83.1 & & & & & & & \\
\hline
\end{tabular}




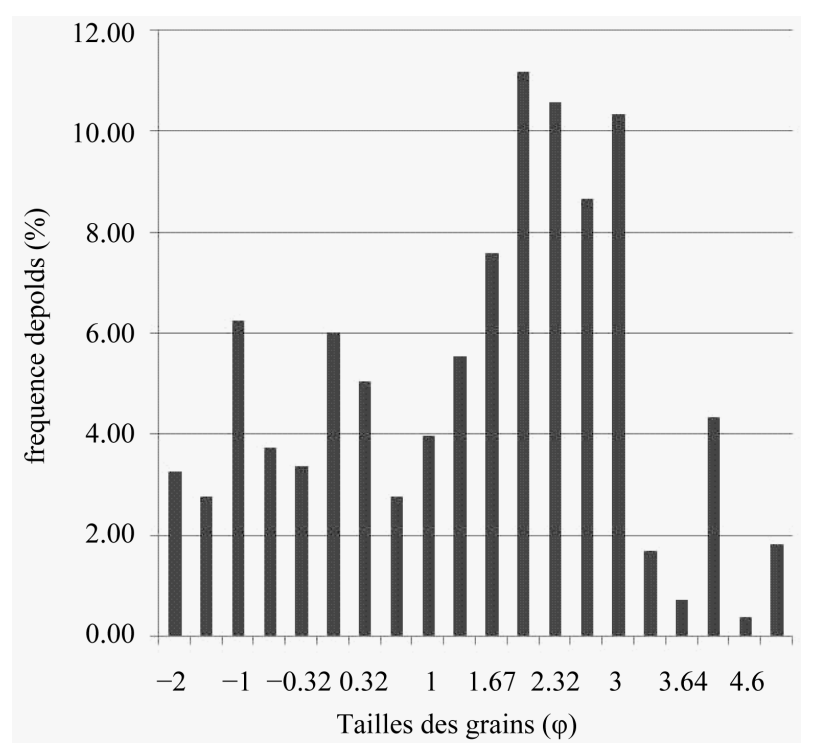

(a)

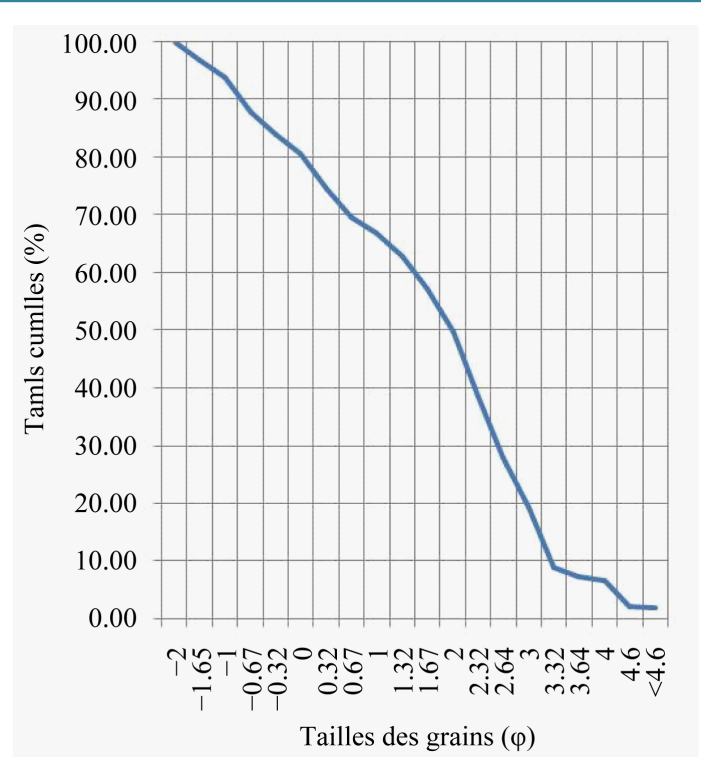

(b)

Figure 3. Graphs (Histograms and canonic curves). (a) Histogramme des frequencies (Ech.2, coupe II), frequency histogram. (Sample 2, Cut II); (b) Coutbe canonique (Ech.2, coupe II), Canonic curve (Sample 2, Cut II).

Table 2. Recapitulative of sedimentlogic parameters of the El Kouif sector.

\begin{tabular}{|c|c|c|c|c|c|c|}
\hline Sample No. & Md (mm) & Mz (Ø) & $\delta \mathrm{i}(\varnothing)$ & Ski (Ø) & Kg (Ø) & $C(\mathrm{~mm})$ \\
\hline 1 (Sec I) & 307 & 1.34 & 1.65 & 0.77 & 2.28 & 3086 \\
\hline 2 (Sec I) & 273 & 1.56 & 1.56 & 0.03 & 3.16 & 3528 \\
\hline 4 (Sec I) & 473 & 1.08 & 1.90 & 0.04 & 0.74 & 3864 \\
\hline 5 (Sec I)) & 226 & 1.80 & 1.66 & -0.59 & 0.28 & 3287 \\
\hline 6 (Sec I) & 180 & 2.44 & 1.00 & 0.74 & 5.37 & 882 \\
\hline 8 (Sec I) & 244 & 1.72 & 1.38 & 0.77 & 2.43 & 3411 \\
\hline 10 (Sec I) & 197 & 2.10 & 1.27 & -0.73 & 3.89 & 1595 \\
\hline 1 (Sec II) & 291 & 1.36 & 1.83 & -0.13 & 1.35 & 3766 \\
\hline 2 (Sec II) & 253 & 1.59 & 1.68 & -0.69 & 2.23 & 3737 \\
\hline 5 (Sec II) & 443 & 1.13 & 1.82 & 0.46 & 1.05 & 3807 \\
\hline 6 (Sec II) & 343 & 1.25 & 1.86 & -0.72 & 0.81 & 3894 \\
\hline 8 (Sec II) & 762 & 0.73 & 1.85 & 0.89 & 0.49 & 3883 \\
\hline 1 (Sec III) & 387 & 1.89 & 1.77 & 0.88 & 1.60 & 3561 \\
\hline 2 (Sec III) & 323 & 1.27 & 1.95 & 0.03 & 1.69 & 3907 \\
\hline 5 (Sec III) & 507 & 1.06 & 1.93 & 0.31 & 0.71 & 3876 \\
\hline 6 (Sec III) & 400 & 1.16 & 1.93 & 0.30 & 0.94 & 3830 \\
\hline 8 (Sec III) & 289 & 1.42 & 1.77 & 0.78 & 2.23 & 3265 \\
\hline
\end{tabular}

- Values of Skewnes faithfully reflecting the complex shapes of histograms.

- The frequency curves are usually multiple graphic types indicating the Kurtosus.

- The median values calculated are included primarily in the sand fraction of medium and fine sizes.

- The figures calculated percentiles end to class rudites (granules).

- Values are mean diameters of classes of sands and medium end. 
- The dispersion values are classified in the interval (1.2) which is learning about grains misclassified.

The sum in fractions analyzed show a certain predominance of grains of sand fine and very fine with an occasional enrichment of coarse and very course (Rudites). In other words, it is mainly the result that they are fine sandy phosphorites very fine ( $40 \%$ - 50\% arenites) with a moderately lower of $5 \%$ to $8 \%$ clay cement.

About mineralogical analysis: the separation with leaguers dense is repeated carefully for some samples. The results are shown in the attached Table 3. They show a predominance of light minerals and occasionally heavy minerals. Then the careful examination for sediment post-split showed the presence of different minerals procession. According to their physical properties, they can be distinguished into: The leucocratic minerals are the most dominant (Phosphate pellets and less degree silica, gypsum and calcite) and melanocratic and colored heavy minerals (apatite components and also iron oxides (hematite, magnetite, limonite etc.), cinnabar, glauconite and dolomite.

Otherwise the analyzed fraction is mainly:

a) Phosphate pellets (Photo 2): The size particles arenites and lutites are spherical or ovoid shape, the rounded surface can be imperfect. However, examination of the mineralized grains, whose external shape is similar to that of pellets micrite. Whichever category of densitometric cuts contained in the heavy fraction slightly they do not exhibit a uniform surface. They carry organic matter at varying rates , which gives them hues ranging from light yellow to very dark brown or opaque.

b) Non-phosphate Minerals (Photo 3): In addition to the mineral fraction, there is in these accumulations sometimes a significant part of non-phosphate minerals. They are characterized by the same particle size as the mineral fraction. The same minerals are found in all profiles. The most common are silica and glauconite also the carbonates and sulphates [14]:

b.1. Silica (Quartz and agate): Quartz almost is granulometric and may also have an angular appearance. Agate is concentric zonal appearance typical.

b.2. The glauconite: presents nipples green light to very bright green. The intensity of the color being dependent on the degree of crystalinity of the mineral [15]. Sometimes sections show even more intense than the iron

Table 3. Densemetric Separation results of El kouif samples.

\begin{tabular}{cccccc}
\hline Number of sample & Initial weight (g) & $\begin{array}{c}\text { Weight of heavy } \\
\text { minerals (g) }\end{array}$ & $\begin{array}{c}\text { Weight light } \\
\text { minerals (g) }\end{array}$ & $\begin{array}{c}\text { (\%) heavy minerals } \\
\text { (\%) light minerals }\end{array}$ \\
\hline Samp: 01-I & 7.0 & 1.2 & 5.8 & 17.14 & 82.86 \\
Samp: 10-I & 7.0 & 0.6 & 6.4 & 08.57 & 65.71 \\
Samp: 08-II & 9.0 & 2.4 & 6.6 & 26.67 & 73.33 \\
Samp: 02-II & 9.5 & 0.2 & 9.3 & 02.11 & 97.89 \\
Samp: 05-III & 10 & 0.1 & 9.9 & 01.00 & 99.00 \\
Samp: 08-III & 6.0 & 0.1 & 5.9 & 01.67 & 98.33 \\
\hline
\end{tabular}

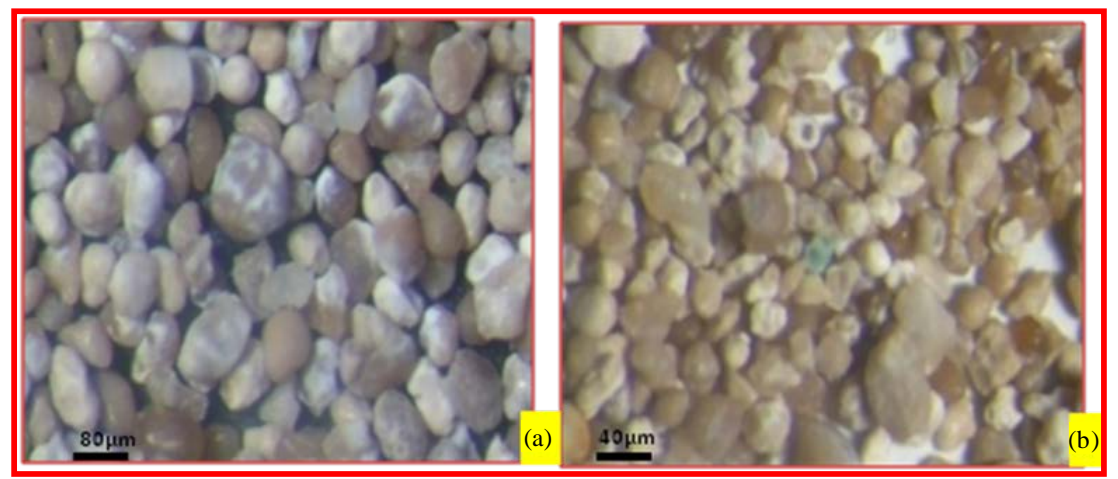

(a)

(b)

Photo 2. Phosphate pellets. (a) Phosphorit grain of the class arenits; (b) Phosphorit grain of the class of lutit. 


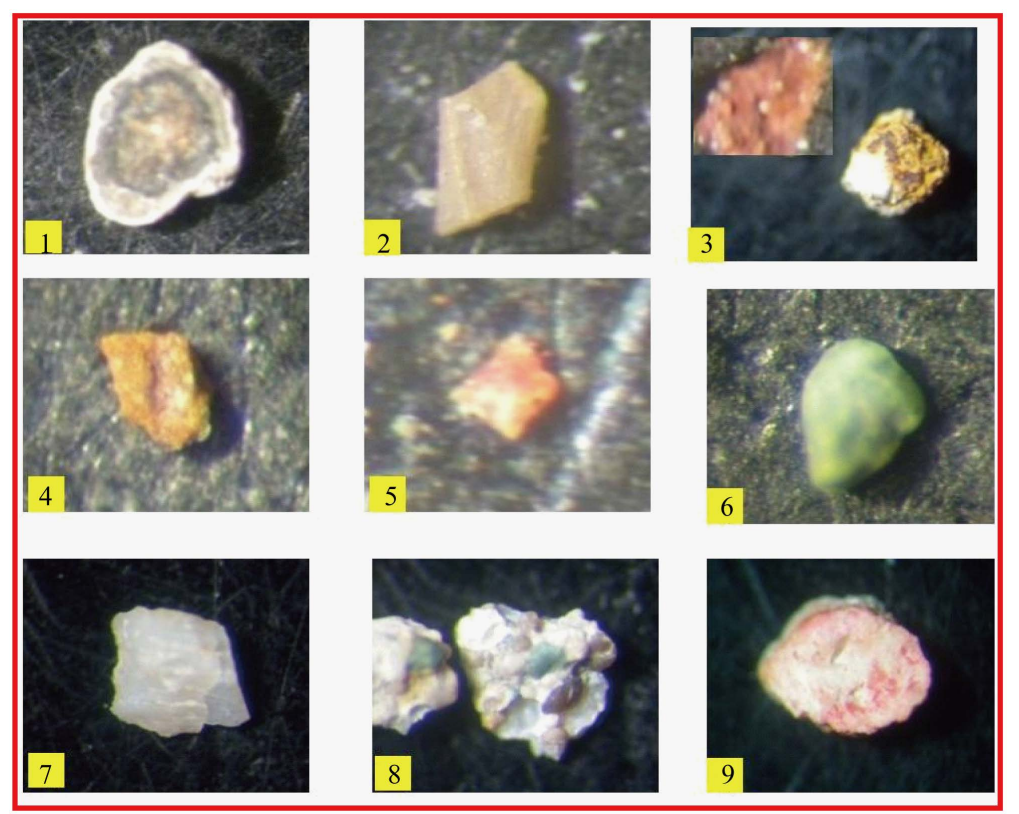

Photo 3. Non phosphatic minerals. 1. Qurtz; 2. Gyps; 3 and 4. Iron oxyds; 5. Altered carbonats; 6. Glauconit; 7. Dolomits; 8. Agglutineted Phosphorites; 9. Cinabr.

content in the network of the mineral exchange oxidation brownish hues.

b.3. Cinnabar: Characterized by high specific weight and vitreous luster is carmine red to brownish red.

b.4. The dolomite: The rhombs are in the dense fraction of brownish color distinguishable.

b.5. Gypsum: The euhedral to sub-hédral silky platelets.

b.6. Clay sparite: Small crystals clear and dark color because of the presence of the organic material forming the bond phosphorites friable.

c) The rudites or coarse fraction were isolated directly with the naked eye and are:

c.1. The coprolites (Photo 4): These fossil fecal are recognized as a wide variety of shapes: cylindrical (1), round, ovoid or oval (2) spiral (3), conical (4), discoid (lenticular) (5a) and irregularly shaped (5a).

In the most common and are more fragile than pellets cases, they are found in the form of fragments, supporting the hypothesis redesign originally accumulations of phosphorite. Many authors have questioned their use in biostratigraphic, but objectively, their allocation to an aquatic animal precise form (fish, reptiles, amphibians or) is risky.

c.2. Bioclasts [16]: are fish teeth and bone fragments of variable sizes and shapes and are in most cases completely phosphated. A test to determine the species of these Chondrichthyans was conducted in accordance with all current views; lingual, labial and profile. Finally, it was identified as a multitude of species of different sizes according to Odontaspidae in [17].

c.3. Lithoclasts; they are hard to break, beige or gray with a shiny black patina similar to coarse gravel, not characterized by any typical form, and can be assimilated at first to lithoclasts phosphorite.

RX Characterization or The XRD analysis performed on samples from phosphate beam of El kouif helped highlight the following main groups of minerals:

1. Apatite may be; hydroxylapatite, fluorapatite, and francolite dahllite (Figure 4):

-Hydroxylapatite $\mathrm{Ca}_{5}\left(\mathrm{PO}_{4}\right)_{3}(\mathrm{OH})$ : The mineralogical study by X-ray diffractometry of the total rock phosphorite and apatite grains purified showed overwhelmingly almost systematic presence of Hydroxylaptite. Main lines of the mineral occurring in the diffractograms correspond to the most studied as follows intense peaks or lattice planes (211), (300), (112), (202), (102), (210), (130), (222), (100), (312), (213), (200), (231), (140), (402), (004), (502), (002). The predominant mineral occurs either single or associated with fluorapatite, and francolite dahllite. Other non-phosphate mineral constituent's exo-matrix; there are coexisting carbonates, Silica, Sulfates and sulfides. 


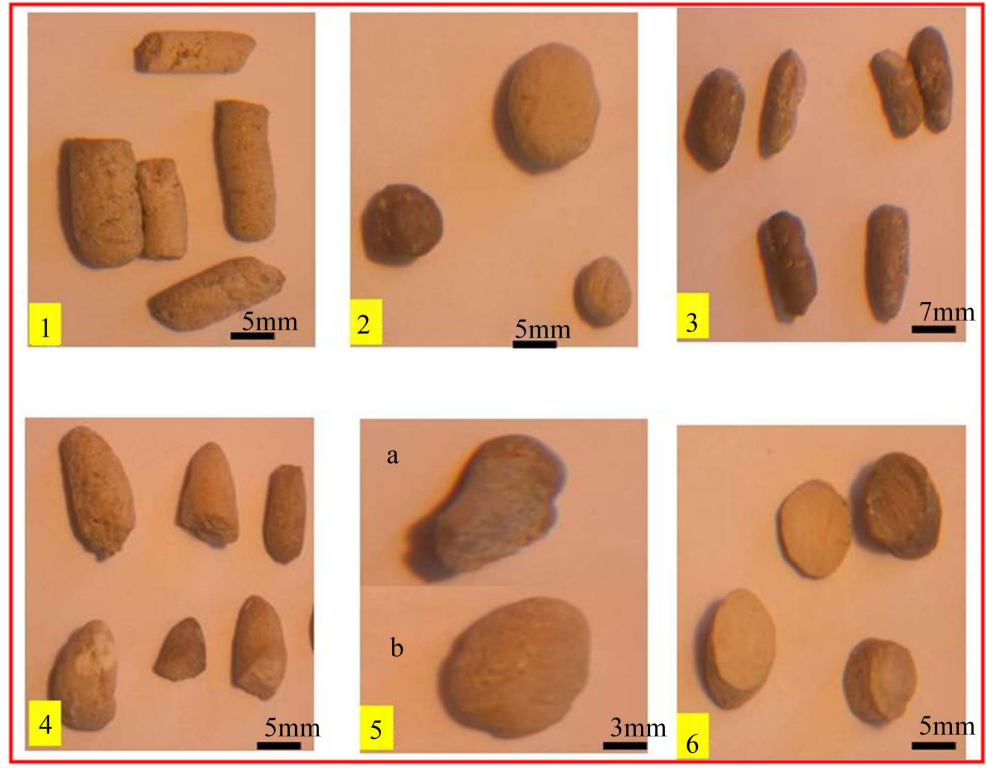

Photo 4. Divers forms and sizes of coprolits in state whole and fragmentary. 1. Forme cylindrique; 2. Forme ronde (ovoïde); 3. Forme spirale; 4. Forme conique; 5a. Forme irrégulière; 5. Forme lenticulaire (discoïde); 6. Fragment de coprolithes en section basale.

-Fluorapatite $\mathrm{Ca}_{5}\left(\mathrm{PO}_{4}\right)_{3} \mathrm{~F}$ : This mineral is associated with hydroxylapatite, apparently mainly characterized nival rich in bioclasts (tooth and bone fragments). This suggests that the teeth likely not undergone significant changes and/or major structural changes during the phosphatogenesis.

-Francolite $\mathrm{CaF}(\mathrm{Ca}, \mathrm{C})_{4}\left[(\mathrm{P}, \mathrm{C})(\mathrm{O}, \mathrm{OH}, \mathrm{F})_{4}\right]$. Rarely shows at phosphtic El kouif layers, it is associated with hydroxylapatite therefore seems not characterized by quantitative dominance our deposit compared to other deposits of North Africa.

-Dahllite $\left(\mathrm{Ca}_{9.35} \mathrm{Na}_{1.07}\right)\left(\mathrm{PO}_{4}\right)_{5.46}\left(\mathrm{CO}_{3}\right)_{1.36} \mathrm{O}_{2}$ : This mineral of calcium-phosphate soduim carbonate present crystallographic parameters (a and c) relatively higher than those of other apatites (perhaps because of strong chemical substitutions). A rarely been met, the Dahllite is associated with hydroxylapatite and quartz.

Crystallographic analysis of the various samples from the phosphate components of El Kouif profiles shows that this apatite belongs to hexagonal crystal system and the space group P63/m with cell parameters: $\mathrm{a}=\mathrm{b}=$ $9.335 \pm 0.02 \AA$ and $\mathrm{c}=6.880 \pm 0.004 \AA$ (Table 4). By comparison between the different apatitic compounds, one of the characteristics is different is the isomorphic substitution in the crystal lattices of $\mathrm{PO}_{4}^{3-}$ by the ions $\mathrm{CO}_{3}^{2-}, \mathrm{OH}^{-}$by $\mathrm{F}^{-}$et $\mathrm{Ca}^{2+}$ by $\mathrm{Na}^{+}$. The latter apparently cause a slight fluctuation of the parameters "a" and "b" when the parameter "c" remains relatively constant [18]. Effectively, results of El Kouif do not contradict this.

2. Carbonates: are present as calcite, magnesium calcite, ankerite and dolomite.

Calcite is characterized by its main line (104) at a distance of 3.058 (Figure:). Sometimes, the main peak $\left(29,179^{\circ}\right)$ has a slight shift to larger angles. This displacement results from the incorporation of the magnesium and/or iron in the structure of calcite. Indeed, the brand magnesium calcite $29.50^{\circ}$, dolomite and ankerite $30,815^{\circ}$ to $30,819^{\circ}$ (Table 5). Associations; calcite-ankerite, calcite and calcite-dolomite-calcite magnesium are recorded on the same samples, which provide information on phenomena matasomatiques dolomitization and dedolomitisation. Thus, dolomite and magnesian calcite characterize cherty levels associating with opal (Tridymite).

3. Free silica: The Quartz $\alpha$ is identified by its main line (011) to $3.33 \AA$. It is often associated with only apatite (HA, FA, FR and Dahllite) and sometimes in the presence of cristobalite and ankerite. It probably has a detrital origin. However, other varieties of opal (cristobalite-tridymite) are encountered at high levels in cherty levels accompanied dolomite and magnesian calcite (Figure 5). Its origin is probably biochemical [19].

4. Gypsum: With its main peak (200), d (6.003 $\AA$ ) and $2 \theta$ (14.745) is sometimes encountered in diffractogrammes. Presumably, it is secondary gypsum. This may result, in an arid climate, the precipitation of rain water 


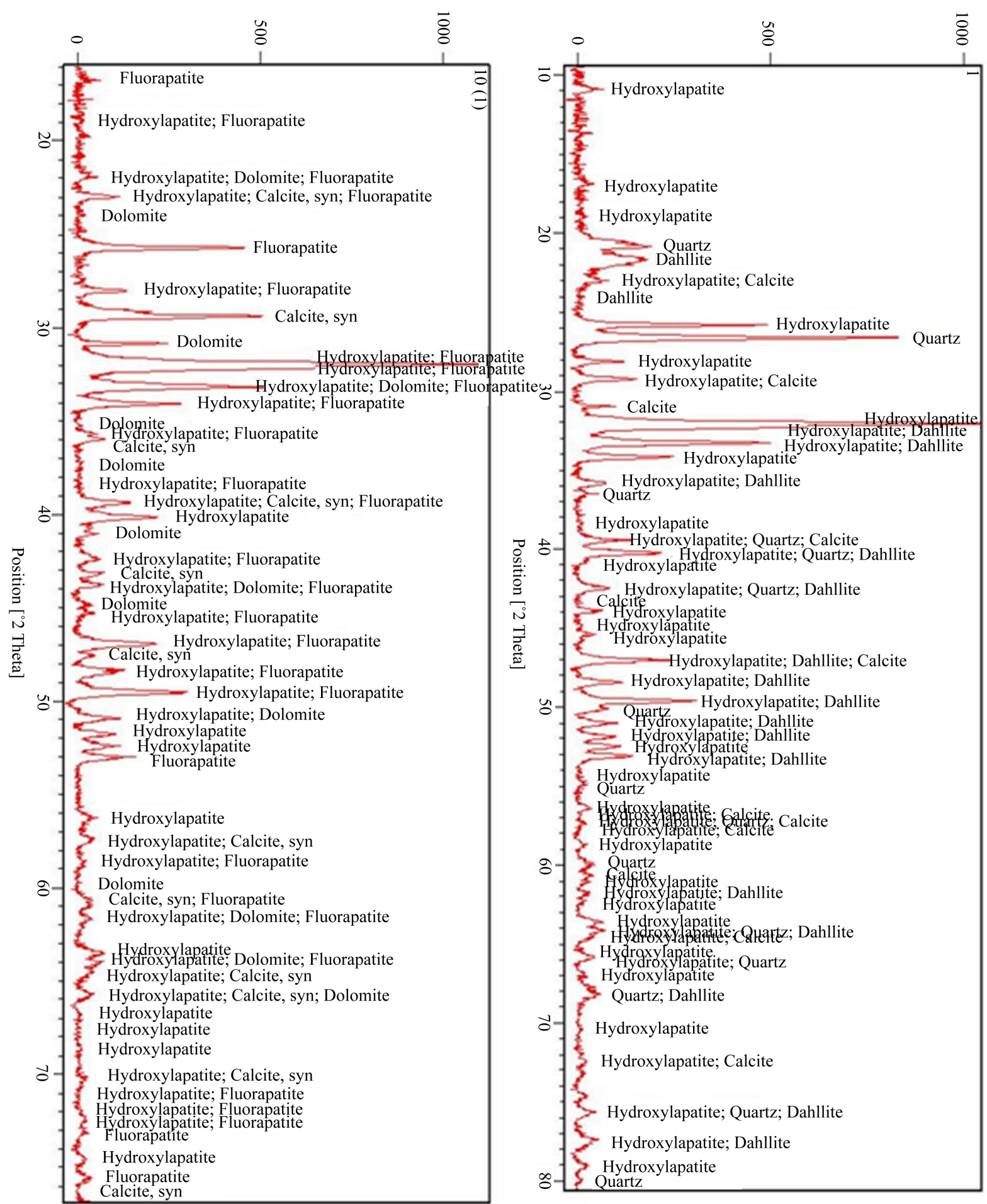

Figure 4. Examples of X ray diagram for phosphorite sample show the apatitic different component with carbonates and siliceous gangue of El Kouif sector.

enriched in sulfate runoff from overlying formations. Especially, evaporite formations are one of the features characterizing this region diapirs (Figure 6(d)).

5. Sulfides: Pyrite-Cinnabar-Covellite to low levels apparently (trace) are detected on the RX recordings of different samples of the same vertical profile of well individualized peaks (see figure). Moreover, the association 
Table 4. Crystallographic parameters of different apatites of El Kouif.

\begin{tabular}{cccccc}
\hline Mineral & $\mathrm{a}$ and b & $\mathrm{c}$ & $\mathrm{c} / \mathrm{a}$ & Mesh & Emperical formula \\
\hline Fluoroap atite & 9.371 & 6.885 & 0.734 & 523.12 & $\mathrm{Ca}_{5}\left(\mathrm{PO}_{4}\right)_{3} \mathrm{~F}$ \\
Hydroxylapatite & 9.352 & 6.882 & 0.735 & 521.26 & $\mathrm{Ca}_{5}\left(\mathrm{PO}_{4}\right)_{3}(\mathrm{OH})$ \\
Francolite & 9.340 & 6.880 & 0.736 & 519.77 & $\mathrm{CaF}(\mathrm{Ca}, \mathrm{C})_{4}\left[(\mathrm{P}, \mathrm{C})(\mathrm{O}, \mathrm{OH}, \mathrm{F})_{4}\right]$ \\
Dahllite & 9.450 & 6.885 & 0.725 & 532.09 & $\left(\mathrm{Ca}_{9.35} \mathrm{Na}_{1.07}\right)\left(\mathrm{PO}_{4}\right)_{5.46}\left(\mathrm{CO}_{3}\right)_{1.36} \mathrm{O}_{2}$ \\
\hline
\end{tabular}

Table 5. Crystallographic parameters of different carbonates of El Kouif.

\begin{tabular}{|c|c|c|c|c|}
\hline Mineral & hkl & $\mathrm{d}(\AA)$ & $2 \theta$ & Chimical formula \\
\hline Calcite & 104 & 3.0360 & 29.395 & $\mathrm{Ca}\left(\mathrm{CO}_{3}\right)$ \\
\hline Calcite magnés & 104 & 3.0254 & 29.500 & $\left(\mathrm{Ca}_{0.97} \mathrm{Mg}_{0.03}\right)\left(\mathrm{CO}_{3}\right)$ \\
\hline dolomite & 104 & 2.8893 & 30.815 & $(\mathrm{Ca} \mathrm{Mg})\left(\mathrm{CO}_{3}\right)_{2}$ \\
\hline Ankérite & 104 & 2.8890 & 30.819 & $\mathrm{Ca}\left(\mathrm{Mg}_{0.67} \mathrm{Fe}_{0.33}\right)\left(\mathrm{CO}_{3}\right)_{2}$ \\
\hline
\end{tabular}

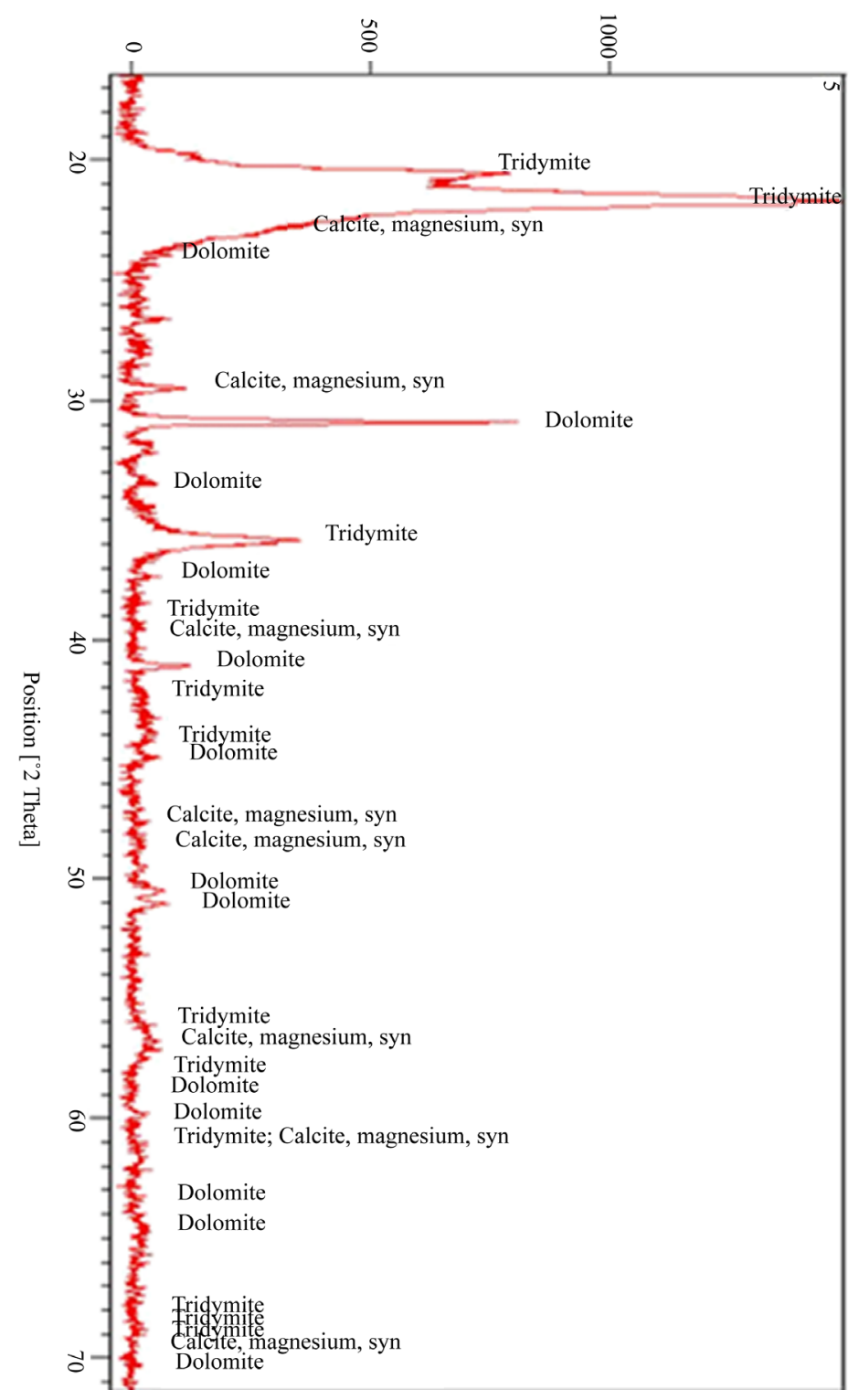

Figure 5. X ray diagram of silex sample in El Kouif sector. 


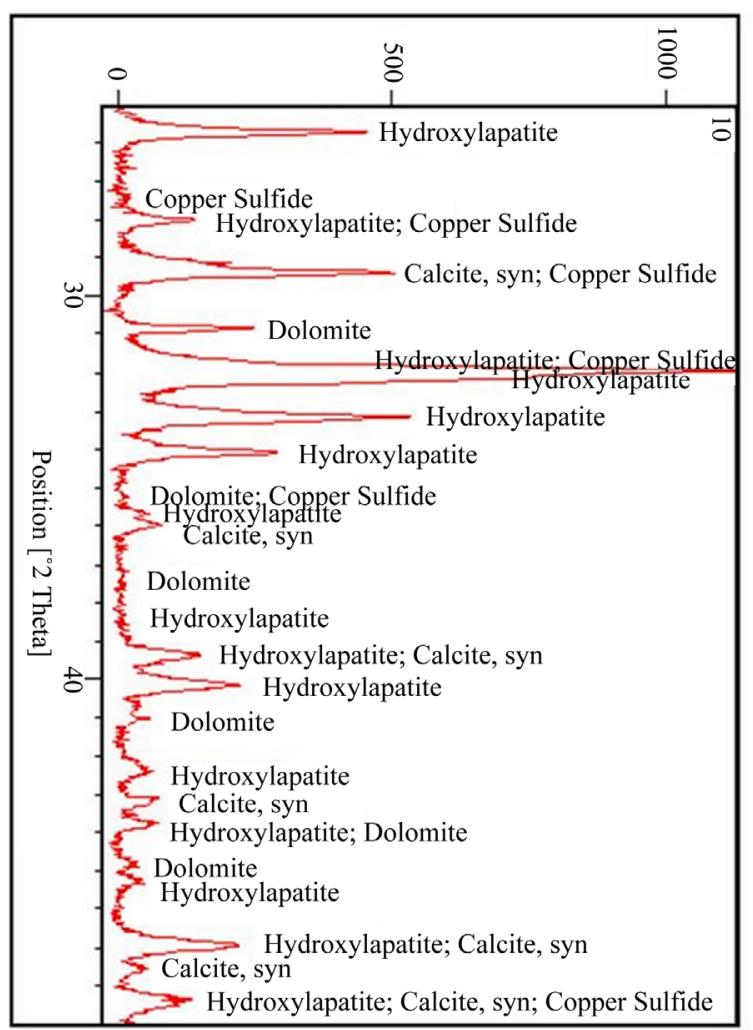

(a)

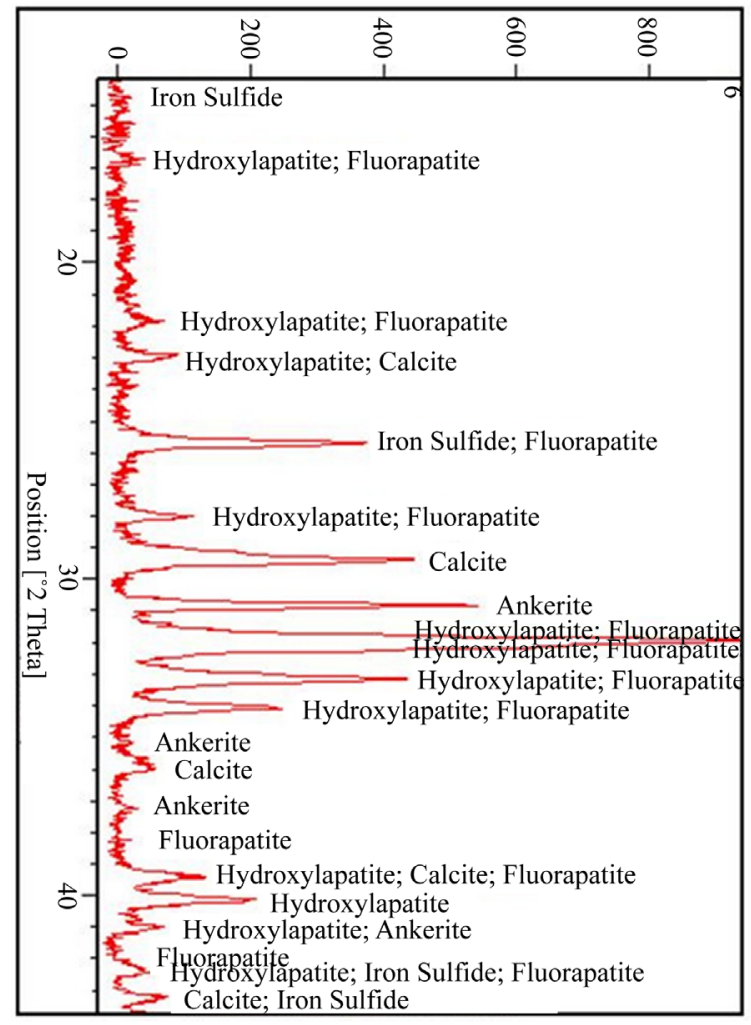

(c)

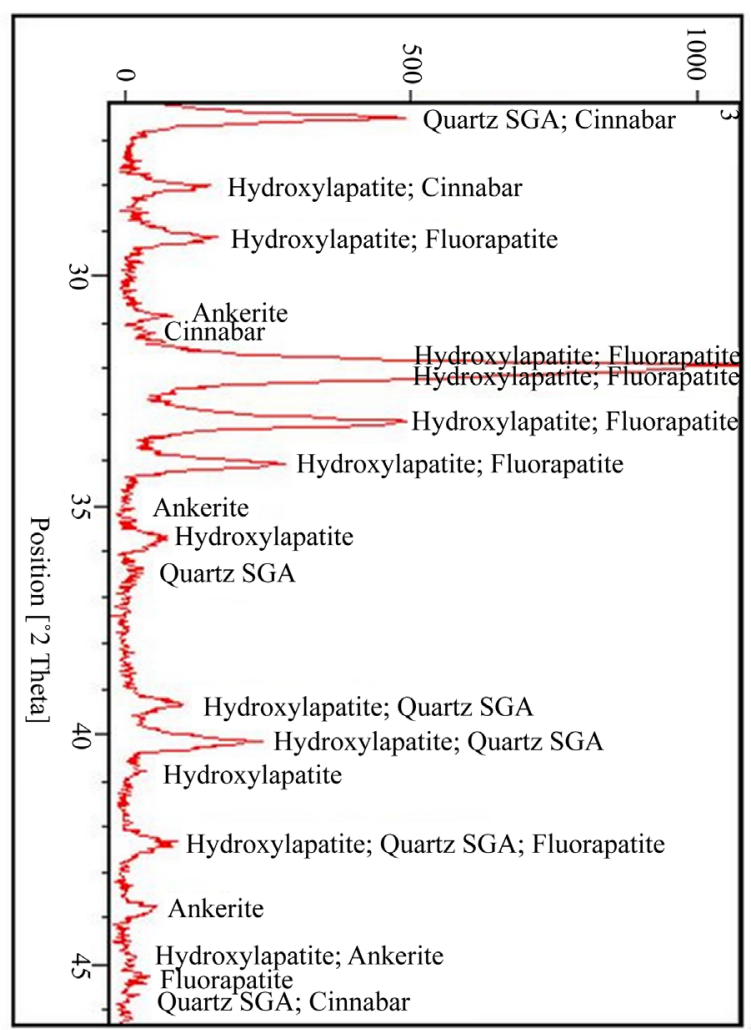

(b)

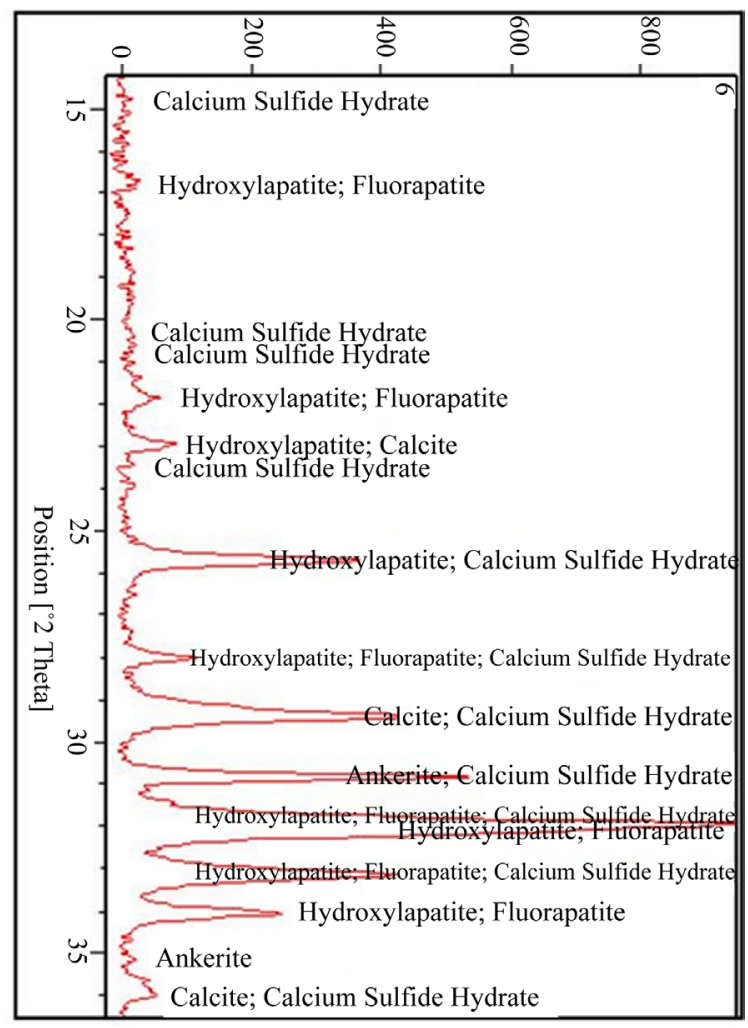

(d)

Figure 6. (a)-(d) Example of X ray diagram show the presence of Carbonates, quartz, Sulfides and sulfates in phosphorites samples in El Kouif sector. 
(Cu-Fe-Hg) is well supported in the region by the expression polymetallic hydrothermal mineralization (Figures 6(a)-(c)).

About the Petrographic Analysis of Phosphorites: the elements of the main phase (allochems) are across all studied profiles are represented by grains of phosphate, quartz, feldspar, glauconite, and tests microfaunal lithoclasts.

1. Pellets (Photo 5): These are the most abandons elements in all phosphorites layers. Also, they are found preferentially in limestone and marly limestone phosphate. However, examination of the mineralized grains, whose external shape is similar to that of pellets micrite has, identifies two broad categories: lack nuclei pellets and pellets nucleated.

1.1. Pellets without nuclei: distribution of organic matter is the major criterion of differentiation [20] [21]:

-Organic matter collected in the center, leaving the rest of lighter grain.

-Organic matter limited to the peripheral zone (pseudo-zonation).

-Organic matter unevenly distributed.

-Organic matter leached or spotted.

-Abundant organic matter across the grain confident the particle dark tint or opaque.

The term organic matter used in this context, both the whole group differentiated whatever their size, shape or arrangement opaque stains. Otherwise, the substance that gives the pellet and other phosphatic clasts, range in color from yellow brownish-tan to dark brown to black. The observation differentiates the organic material of iron oxides by the absence of the characteristic red color of the oxides.

1.2. The pellet cores: The cores are inorganic solid particles used to support the apatite during growth pellet. In all cases, the coating gives pellets their rounded or ovoid shape.

The nucleus phosphates included within the pellets are clasts and bone fragments coprolites, and other phosphate grains. They are visible in natural light microscopy due to their identical to the mineralogical composition of the envelope. Note also the presence of radiolarian tests épigénisés apatite and encapsulated. However, some

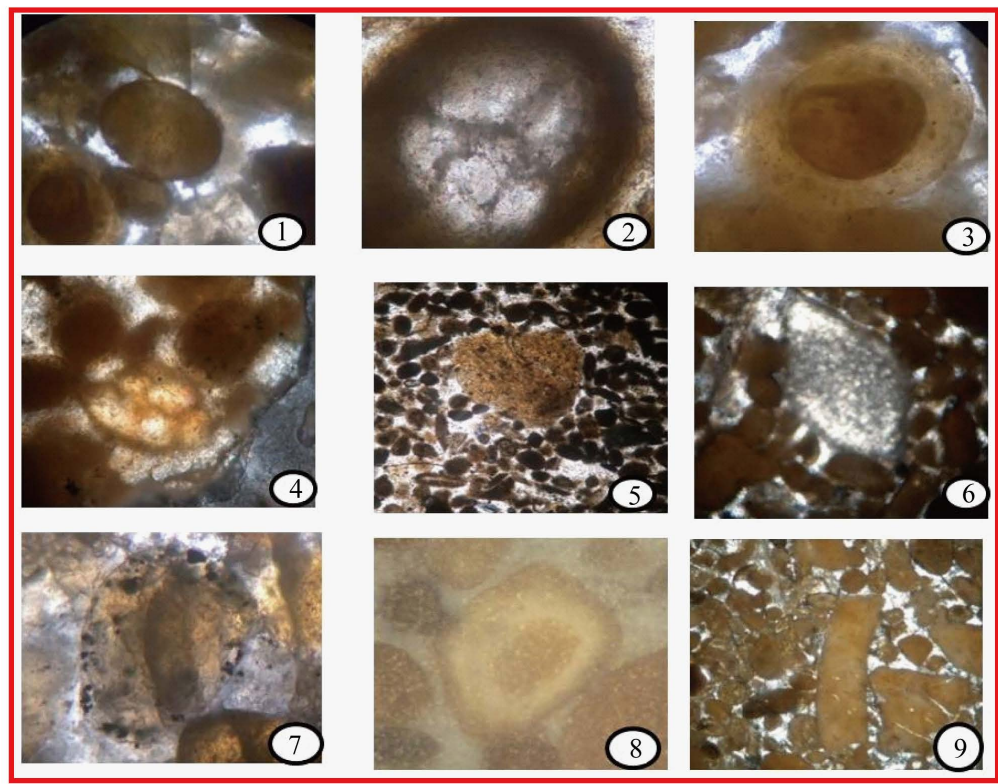

Photo 5. The phosphates elements of the main phase of phosphorites in El Kouif sector. 1. Pellets dépourvus de noyaux montrant la répartition abondante et inégale de la matière organique. 2 . Foraminifère à test de calcite entouré d'apatite riche en matière organique. Ech22 coupe H. 50x L,PA. 3. Pellet à gros noyau de phosphate riche en matière organique encastré dans une enveloppe plus claire. 4 . Globigérine servant de noyaux pour un oolithe phosphaté. £ch. 18 Coupe I [.50x.l .l'A. 5. Granule phosphaté à angle émoussé dans une pel-phospharénite. Ech 16 Coupe II.5x LPA. 6. Rhomboèdre de dolomie cryptocristalline à pourtour apatitique. Echl5coupe II.20x .LPA 7. La matière organique est disposée suivant un cercle incomplet, le long du pourtour d'un pellet. 8. Pellet montrant une croissance en zonation (aspect concentrique). Ech.9 coupe I.20x. 9. Coprolithe de forme cylindrique dans une phosphorite hétérométrique. Ech..27. Coupe II.10x. 
pellets contain similar mineral grains to those present in the middle of the deposition. We identified the presence of quartz, glauconite, dolomite rhombs of calcite and épigénisés tests.

2. The coprolites and lithoclasts (Photo 6): They vary in size but are mineralogically similar to the pellets (same optical characters). They may lack internal structure, but there often observed and thin tracks hyaline apatite more elongated, intersecting lines or drawing meandering, equal or unequal thickness. They all have in common an extremely microcrystalline apatite dough uniform color without bias.

3. The bone fragments and teeth of fish: The bone fragments in sedimentary phosphorites are made of apatite. However bone microstructure is typical elongated, hollow fibers for some bony structure clasts largest dimension. Often microscopic examination reveals structure in the arrangement of the organic matter. LPA was observed a succession of still off strips and polarizing bands in the gray of the first order. Grouping in this category teeth vertebra in different sections (longitudinal, transverse and oblique) (Photo 7):

In addition to the mineralized fraction, there is in these accumulations sometimes a significant part of nophosphate minerals. Usually they are not distributed in a homogeneous manner in deposits. They are characterized by the same particle size as the mineral fraction. They are: Silica crystals or crystal aggregates sometimes idiomorphic quartz hyaline, Feldspars rare but there was feldspars subhedral to euhedral and Glauconite present at low levels in the mineralized layers. Glauconite is presented nipples green to light green.

The binding phases at various rates ranging from loose grains to completely indurated by a phase of significant and lethifiate binding material (Photo 8).

A) Phase clay link: Furniture phospharénites or phosphatic sand (sieved samples) usually contain a clay matrix amount small enough that the texture is kind of wakestone-packstone.

B) The carbonate cement: Carbonates were observed when the porous intergranular space is of the same order of magnitude as the pellets. It is sometimes dolomite rhombs subhédraux including some faces which are well separated but whose development stops in contact with pellets and other grains limiting the pore space. The outline of these rhombs indicates that they are formed after the filing and settling of particles and they receive for their growth, volume remained vacant.

C) Siliceous cement: Primary silica cements are difficult to establish unambiguously. Levels in which silica is the binding phase are more likely secondary origin. The silica usually extends internally of sediment when the

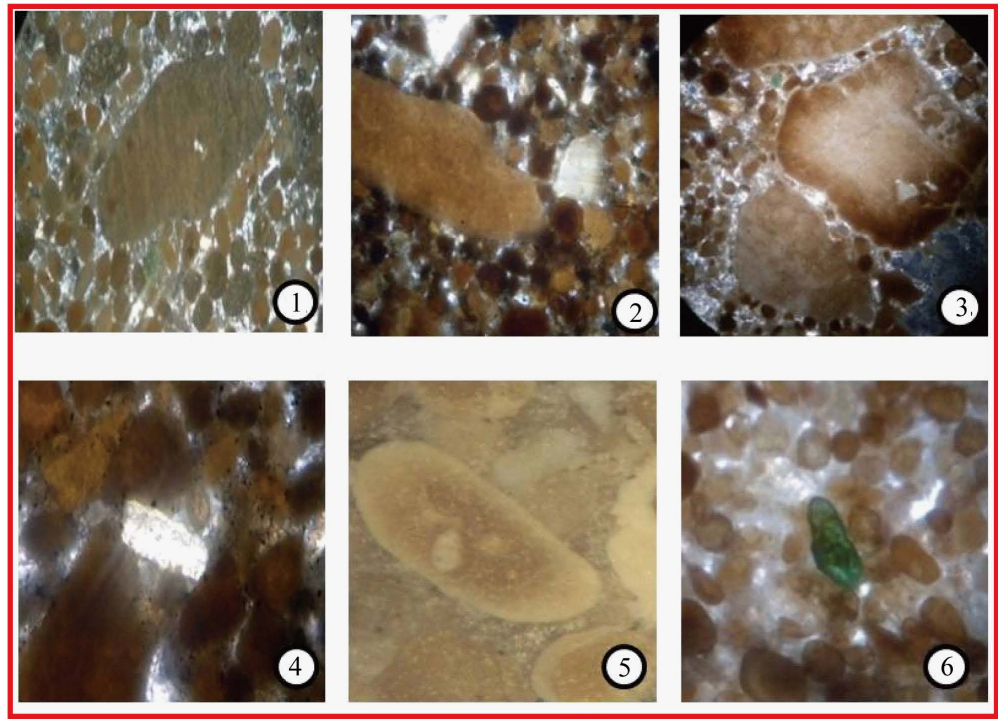

Photo 6. Other elements no-phosphate of the main phase of phosphorites in El Kouif sector. 1. Coprolithe de forme ovoïde dans une phosphorénite à texture grainstone; 2. Coprolithe de forme irrégulière dans une phosphorénite hétérométrique; 3 . Gros clastes de granules phosphatés dans une matrice spatho-sparitique; 4 . Section rectangulaire de feldspaths dans un grainstone apatitique. Coupe III. Ech 3. 20x.5; 5. Pellet à cortex apathique plus clair entourant plusieurs composants d'apatite hétérogénique. Ech.4 coupe II.5x. LR; 6 . Grain de glauconie verte de forme allongé dans une phospharénite. 


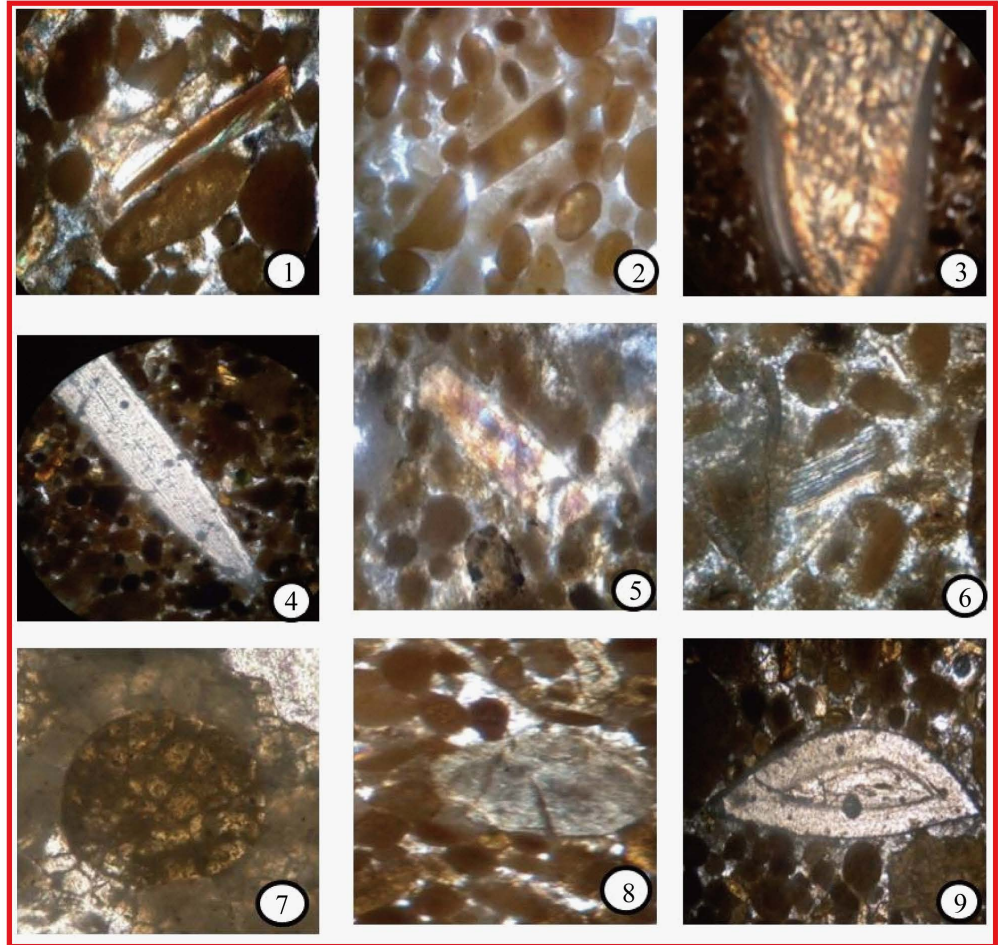

Photo 7. Bioclasts and elements of the main phase of phosphorites in El Kouif sector. 1. Fragment osseux phophatisé de forme allongée dans un biopellmicrosparite. 2. Rhomboèdre phosphaté dans une pellphospharenite. Coupe I Ech. 3. 5x. 3. Dent sélacien épigenèsé par de l'apatite des bords extérieurs, cependant le moule interne est une calcite sparitique. Coupe I Ech. 3.5x. 4. Fragment d'os à terminaison anguleuse. 5. microstructure d'un fragment d'os. La frange est d'apatite cependant le canal est en morceaux calcitiques. 6 . Cristal aciculaire de plagioclase, dans une phospharite anisogranulaire. 7. Radiolaire épigenèsé par de l'apatite microcristalline. ech.9 coupe III.50x. 8. Microfossile (radiolaire) dans un biopellphospharénite à texture grainstone. 9. Section basale d’une dent marquée de la matière organique .Coupe II Ech. 7. 1Ox.

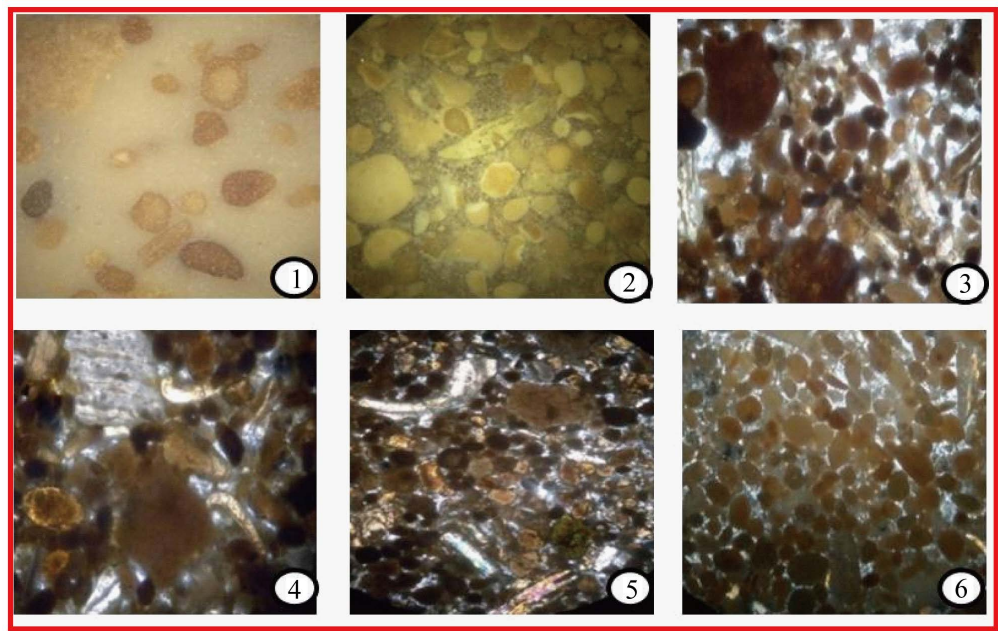

Photo 8. Différent textures of phosphorites in El kouif sector. 1. Wackstone siliceuse (Quartz amorphe) à allochèmes phosphatés Ech 9 Coupe II 5x LR. 2. Facies packstone à éléments phosphatés (pellets, os, coprolithe, lithoclaste) hétérométrique dans ciment carbonate micritique. Ech 9 Coupe II.10x. LR. 3. Phospharénite anisogranulaire (pellet, oolithe et os) de texture packstone. 4. Bio-phospharénite à coquille d’Ostrea, clastes et fragments osseux. 5. Bio-pelphospharénite de texture grainstone, les allochèmes sont représentés par des pelllets, lithoclastes et bioclastes calcitiques. Coupe II Ech .7. 6. Phospharénite iso granulaire de texture grain stone. Coupe I Ech. 3. 5x. 
main phase grains are not contiguous. Intergranular voids are occupied mainly by extremely small anhedral quartz crystals, which can become a little larger locally.

\section{Conclusions}

One of the Paleo-Eocene phosphatic accumulations in Algeria is that the area of El Kouif mountain. This makes part of the north-east of the Algerian-Tunisian border.

This approach has been proposed to help clarify the mechanisms and conditions prevailed during the phosphatogenesis of the already mentioned sedimentation.

The summary description of macroscopic three studied Cups allowed us to decide on a lithologically phosphate beam without sterile intermediate, topped by a blanket of carbonate facies, clay and sometimes with phosphatized horizons tonsils chains flint.

Particle size analysis of phosphorites sandy clay to cement (after wet screening) revealed that we analyzed sediment mark some predominance of very thin and fine fractions (40\% to 50\% of Arenites) with an enrichment of random coarse (Rudites) clay and cement low (5\% - 8\% lutites). Thus, analytical data processing shows that heterometric and deposits are often misclassified. The irregular distribution of pellets in phosphorite and casual grouping are redesign testimonies. Ocean currents carry sediment load and removal when their strength suddenly drops. We then obtain unranked deposits when the energy level drops dramatically. The movements of water basins are also responsible for grain sorting that was observed in some phosphorites (winnowing). The concentration of the mineral fraction is through the elimination of a large part of the clay phase and internal carbonate sediment.

Sorting and morphoscopic observation under binocular (mineralogical analyzes) have isolated mainly coarse category coprolites. These are long recognized as having a fecal. We were able to detect a wide variety of forms the most common and are more fragile than the pellets if they are found in a fragmentary state and abraded. This fact supports the hypothesis of reworking during transport to the origin of phosphorite accumulations. In addition, it should be noted that the systematic observation of these biological remains that size fish mark the important organic role and quantitative importance in the morgue during the genesis of phosphates. In addition, the examination under binocular phosphate grains identified spherical pellets morphological and/or sub-spherical. Presumably, the throttling is at the origin of calibration provided sediment grains whose size and mostly in the region of $100 \mathrm{~m}_{\mathrm{u}}$. Furthermore, the larger of the same characteristics that the pellets are few grains.

Moreover, among the elements of the main phase, there exist in these accumulations a significant portion of non-phosphate minerals. Usually, are distributed in a random manner in the deposits. They are characterized by the same grain size as the phosphate particles. They are silicates (silica and glauconite) but also carbonates (calcite and dolomite), sulfates (gypsum) and iron oxides. The coexistence of this irregular mixture (phosphate particles and non-phosphate) of the facies shows the allochthony grains in strata phosphorite. If the glauconite is formed in an open and semi-confined, more oxidant than promoting phosphatogenesis, after Marine microenvironment [15], the mine of our profiles have been transported to the depositional environment through ocean currents. Its lenticular character means an action by coastal currents.

Separation by heavy liquid bromoform $(\mathrm{P}=2.9$ ). Few samples of phosphatic sand (fraction u $80-250 \mathrm{~m}$ ) showed a predominance of lighter pellets. This could be explained either by light or by nucleus porosity and internal voids.

The optical petrographic analysis in transmitted and reflected light samples of phosphate permit beam to better characterize the constituent phases of phosphorites. The elements of the main phase are mainly represented by phosphate-free shovels nucleus variable organic matter content, and to other non-phosphate and phosphate nucleus (nucleus of glauconite, dolomite, quarts and feldspar). Phase's links are clay cement, carbonate or siliceous variable dominance. Whole cases observed types wackestone packstone textures figures correspond to relatively high settlement before indurations of loose sediments. When allochems do not touch that by internal sediment remain, settlement suffered is unimportant. Elements reoriented along planes of contact are the sign of a larger settlement. The implementation of the apatite in siliceous clasts is at constant volume and preservation of the original microstructure. This is the case of radiolarians forming the nucleus of some pellets or those which met free. Phosphate clast constituents of nuclei have been so presorting size. Sometimes they are bonded to each other by a hyaline apatite phase. The absence of typically Oolitic microstructure is to negate the chemical origin of phosphorites. The bioclasts are epigenesed ante deposit. Moreover, the contours of the rhombohedrons that 
are formed indicate dolomitic subsequently depositing particles. The textures are mainly wackstone types, packstone and grainstones sometimes for bio-pel-micrsparites. Incidentally, the feregenisation is the ultimate phase (post-sedimentation) where oxides have benefited for their vacant volume growth and microcracks that are used to drain percolating fluids.

Mineralogical analys is RX samples enriched phosphate grains which has identified the structure and crystallographic parameters describing our apatite components mainly to hydroxylapatite by cons was encountered sporadically in Fuoroapatite, francolite and centerpieces to dahllite levels through the rich bio-clasts. These components are associated mainly apatite in a gangue of exo-carbonates (calcite, dolomite, ankerite), silica and/ or clays. Thus, these binding formant phases have a random distribution across the profiles. The crystallographic study performed on a variety of samples of apatite constituents from El-Kouif profiles show that it belongs to the hexagonal crystal system and the space group P63/m with cell parameters: $\mathrm{a}=\mathrm{b}=9335 \pm 0.02 \AA$ and $\mathrm{c}=$ $6.880 \pm 0.004 \AA$. Compared the various inter composed apatite, a characteristic stand, is isomorphic substitution in the crystal lattices of ions $\mathrm{PO}_{4}$ by $\mathrm{CO}_{3}, \mathrm{OH}^{-}$by $\mathrm{F}^{-}$and $\mathrm{Ca}^{2+}$ by $\mathrm{Na}^{+}$. Past apparently cause a slight fluctuation of the parameter " $a$ " while the parameter “c” remains relatively constant. At cherty passages, opal-CT, associated with dolomite, is the primary mineral. This enrichment opal indicates a silica rich environment at the time of deposition of these layers. Presumably, this is due to precipitated Opal which is significant contribution in test siliceous organisms (radiolarians, diatoms...). Locally, sulfides (pyrite-cinnabar-Covellite) and sulphate (gypsum) are observed through some low representation samples. Indeed, their presence is confirmed in the area of diapirs.

The analysis of the paleontological content extracted by washing brittle facies helped to differentiate bone fragments and teeth spectacular fish. These faunal elements (remains of vertebrates) show a dealer marine. The review for several of these shark teeth we started to distinguish various Odantospdae confirming age Paleo-Eocene layers of phosphorite El-kouif.

In addition, the richness in organic matter is a digenetic sign anoxic conditions associated with the genesis of phosphorites. All in all, it is true that the environment of deposition of "phosphorite grains" is a marine, shallow, coastal and warm environment. Apparently, these analyzes are advocating an immigrant character for this phosphatogenesis. The history of the establishment of a phosphate level is not completed with the genesis of apatite pellets. These phosphatic elements are transported for months, during periods of high energy and the final concentration of $\mathrm{P}_{2} \mathrm{O}_{5}$ and other chemical elements is realized after a winnowing reworked ending in a marine depository.

Finally, this study deserves further work by geochemical analysis of major elements representations existing mineral assemblages.

\section{References}

[1] Flandrin, J. (1948) Contribution à l'étude stratigraphique du Nummulitique algérien. Publications du Service de la Carte géologique de l’Algérie, $2^{\text {eme }}$ Série Stratigraphie.

[2] Sassi, S. (1974) La sédimentation phosphatée au paléocène dans le Sud et Centre Ouest de la Tunisie. Thèse Doct. és-Sci. Orsay.

[3] Chaabani, F. (1995) Dynamique de la partie orientale du bassin de Gafsa au Crétacé et au paléocène. Etude minéralogique et géochimique de la série phosphatée éocène. Tunisie Méridionale, Thèse Doct. Es-Sci . Univ. Tunis II.

[4] Zaier, A. (1984) Etude stratigraphique et tectonique de la région de Sra Ouertane (Atlas tunisien central). Lithologie, pétrographie et minéralogie de la série phosphatée. Thèse Doct. 3rd Cycle, Faculté des Sciences, University of Tunis, Tunis, $163 \mathrm{p}$.

[5] Zaier, A. (1999) Evolution téctono-sédimentaire du bassin phosphate du centre-Ouest de la Tunisie. Minéralogie, pétrographie, géochimie et genèse des phosphorites. Thèse Doctorat, University de Tunis, Tunis.

[6] Baji-Sassi, A. (1984) Pétrographie, minéralogie et géochimie des sédiments phosphatés de la bordure orientale de l’ile de Kasserine (Tunisie). Thèse 3rd Cycle, University of Orléans, Orléans.

[7] Baji-Sassi, A. (2002) Les phosphates dans bassins paléogènes de la partie méridionale de l’Axe Nord-Sud. Thèse de Doctorat, University de Tunis II, 423 p.

[8] Ben Hassen, A. (2007) Données nouvelles sur la matière organique associée aux séries du bassin phosphaté du Sud tunisien (gisement de Ras-Draa) et sur la phosphatogenèse. Thèse de Doctorat, University of Orléans, Orléans.

[9] Ounis, A. (2011) Apport de la géochimie des terres rares et des isotopes pour la compréhension des mécanismes de la 
phosphatogénese: Exemple de la partie occidentale du bassin du Gafsa-Métlaoui. Thèse doct. és-Sci. Univ. Tunis, 141 p.

[10] Chabbou-Moustafai, S. (1987) Etude de la série phosphatée tertiaire du djebel Onk (Algérie): Stratigraphie, pétrographie, minéralogie et géochimie. Thèse Doct. ès-Sci. Univ. Aix-Marseille, France.

[11] Bezzi, N., Aıfa, T., Merabet, D. and Pivan, J. (2008) Magnetic Properties of the Bled El Hadba Phosphate-Bearing Formation (Djebel Onk, Algeria): Consequences of the Enrichment of the Phosphate Ore Deposit. Journal of African Earth Sciences, 50, 255-267. http://dx.doi.org/10.1016/j.jafrearsci.2007.09.019

[12] Fleury, J. (1969) Stratigraphie du Crétacé et de l’Eocène (Aptien à Lutétien) de la feuille 1/50000 morsot, No. 178. Publications du Service de la Carte géologique de l’Algérie (Nouvelle série), Bulletin No. 39, 145-157.

[13] Bles, J. and Fleury, J. (1970) Notice explicative de la carte géologique du MORSOTT(178). Service géologique de l’Algérie Alger, 36 p.

[14] Rosie, H. (2002) Roches, cristaux, minéraux. Guide images. Direction Editoriale ALEXANDRE FOLCO, 223 p.

[15] Odin, S. (1975) Les glauconies. Thèse de Doct. Es-Scie. Naturelles, Université Pierre et Marie CURIE, Paris.

[16] Giovani, P. (1939) L’Encyclopédie des fossiles. Traduction et adaptation de JACQES BLOT directeur de recherches au C.N.R.S Edition Atlas, 232 p.

[17] Cappetta, H. and Nolf, D. (2005) Révision de quelques Odontaspidae (Neoselachi; Lamniformes) du paléocène et de l'éocène du bassin de la mer du Nord. Bulletin de l'.Institut Royal des Sciences Naturelles de Belgique, No. 3, 237 266.

[18] Slansky, M. (1980) Géologie des phosphates sédimentaires, Mem. Du BRGM. No.114-1980, 3 p.

[19] Henchiri, M. (2007) Sedimentation, Depositional Environment and Diagenesis of Eocene Biosiliceous Deposits in Gafsa Basin (Southern Tunisia). Journal of African Earth Sciences, 49, 187-200. http://dx.doi.org/10.1016/j.jafrearsci.2007.09.001

[20] Ben Hassen, A., Trichet, J., Disnar, J.R. and Belayouni, Y. (2011) Pétrographie et géochimie comparées des pellets phosphatés et de leur gangue dans le gisement phosphaté de Ras-Draa (Tunisie). Implications sur la genèse des pellets phosphatés. Swiss Journal Géoscience, 103, 457-473. http://dx.doi.org/10.1007/s00015-010-0029-x

[21] Ben Hassen, A., Trichet, J., Disnar, J.R. and Belayouni, Y. (2009) Données nouvelles sur le contenu organique des dépôts phosphatés gisement de Ras-Draa (Tunisie). Comptes rendus Géosciences, 341, 319-326. 